\author{
Dick G. Markhorst \\ Marc van Heerde \\ Frans B. Plötz \\ Martin C. J. Kneyber
}

\section{Should strict normoglycaemia be maintained in critically ill children?}

Accepted: 4 February 2008

Published online: 19 March 2008

(C) The Author(s) 2008

Sir: Several recent studies clearly identify the development of hyperglycaemia as an important risk factor in terms of mortality and morbidity of critically ill patients. In patients undergoing cardiac surgery, hyperglycaemia has been associated with a substantial mortality risk and delayed extubation [1,2]. Strong evidence favouring a strategy targeting strict glucose control (4.5-6.0 $\mathrm{mmol} / \mathrm{l})$ came from the landmark prospective, randomized, controlled study on intensive insulin therapy in adult surgical critically ill patients [3]. Recently, the clinical benefits of this therapy in adults were largely confirmed in a large, random- ized, controlled trial in a strictly medical adult ICU patient population [4]; however, whether the maintenance of normoglycaemia in critically ill children is also beneficial on patient outcome is undetermined. In an effort to analyse the presently available evidence related to paediatric critically ill patients, we performed a structured critical appraisal of the literature.

In critically ill children (patient) does insulin therapy in order to maintain strict normoglycaemia (intervention) improve survival, or reduce morbidity (outcome)? We have performed the following search strategy: Secondary (Cochrane library) and primary (PubMed) sources were included in the search. These databases were searched for: ("Insulin"[Mesh] or "Hyperglycemia"[Mesh] or "Glucose Metabolism Disorders"[Mesh] or "Glucose"[Mesh]) and ("Critical Illness"[Mesh] or ("Intensive Care"[Mesh] or "Intensive Care Units, Pediatric"[Mesh])) and systematic [sb] not ("Diabetic Ketoacidosis"[Mesh] or "Diabetes Mellitus"[Mesh]). Our search yielded 37 results, five relevant to the question, two related to children. One of the publications used a pooled database [4] partly described in a previous study. [3] One study was non-observational only. The three remaining studies are given in Table 1.

In critically ill adults, it has been shown that maintenance of strict normoglycaemia $(4.5-6.0 \mathrm{mmol} / \mathrm{l})$ with intensive insulin therapy substantially prevents morbidity and reduces mortality [4]. The risk of hypoglycaemia increases with this therapy, but it is unclear whether this is truly harmful in the setting of adult intensive care. In paediatric critically ill patients, hyperglycaemia is prevalent and is associated with a worse outcome $[5,6]$. This association in itself, however, does not imply a causal relation. Whereas in adult studies maintenance of blood glucose levels between 80 and $110 \mathrm{mg} / \mathrm{dl}(4.5-6.0 \mathrm{mmol} / \mathrm{l})$ has shown to reduce both mortality and morbidity [4], in the described paediatric studies higher glucose levels above $150 \mathrm{mg} / \mathrm{dl}(8.3 \mathrm{mmol} / \mathrm{l})$ or above $178 \mathrm{mg} / \mathrm{dl}(10 \mathrm{mmol} / \mathrm{l})$ have been found to be predict mortality $[5,6]$. Uniform criteria to define hyperglycaemia in critically ill children have yet to be established and may differ between age groups. Moreover, the acute phase of sepsis

\begin{tabular}{|c|c|c|c|c|c|}
\hline Reference & Study group & Level of evidence & Outcome & Key results $(95 \%$ CI $)$ & Comments \\
\hline [4] & $\begin{array}{l}\text { Adult ICU patients, } \\
n=2,748 ; \text { conven- } \\
\text { tional insulin treat- } \\
\text { ment group } n=1,388 ; \\
\text { intensive insulin treat- } \\
\text { ment (IIT) group } \\
n=1,360\end{array}$ & $\begin{array}{l}\text { Meta-analysis } \\
\text { (level 1a) }\end{array}$ & $\begin{array}{l}\text { Mortality, } \\
\text { critical illness } \\
\text { polyneuropathy, } \\
\text { renal failure, } \\
\text { hypoglycaemia }\end{array}$ & $\begin{array}{l}\text { Mortality: relative risk } \\
\text { reduction (RRR) } 19 \% \\
\text { (95\% CI: } 2-35 \%) \text {; } \\
\text { absolute risk reduc- } \\
\text { tion (ARR): } 0.03 \\
(0.004-0.056) ; \\
\text { number needed to treat } \\
\text { (NNT): } 33 \text { (18-281) }\end{array}$ & $\begin{array}{l}\text { Study limited to adults; } \\
\text { insulin therapy in the con- } \\
\text { ventional treatment group } \\
\text { was initiated when blood } \\
\text { glucose levels exceeded } \\
215 \mathrm{mg} / \mathrm{dl}(12 \mathrm{mmol} / \mathrm{l}) \text {, } \\
\text { and adjusted to keep blood } \\
\text { glucose between } 180 \text { and } \\
200 \mathrm{mg} / \mathrm{dl}(10-11 \mathrm{mmol} / \mathrm{l}) \text {; } \\
\text { in the intensive insulin treat- } \\
\text { ment group, therapy was } \\
\text { initiated when blood glu- } \\
\text { cose was above } 110 \mathrm{mg} / \mathrm{dl} \\
(6 \mathrm{mmol} / \mathrm{l}) \text { and adjusted } \\
\text { to maintain blood glucose } \\
\text { between } 80 \text { and } 110 \mathrm{mg} / \mathrm{dl} \\
(4.5-6 \mathrm{mmol} / \mathrm{l})\end{array}$ \\
\hline
\end{tabular}

Table 1 Overview of relevant papers 


\begin{tabular}{|c|c|c|c|c|c|}
\hline Reference & Study group & Level of evidence & Outcome & Key results $(95 \% \mathrm{CI})$ & Comments \\
\hline & & & & $\begin{array}{l}\text { New renal failure: } \\
\text { RRR } 42(18-65), \text { ARR } \\
0.032(0.014-0.050), \\
\text { NNT } 31(20-71)\end{array}$ & \\
\hline & & & & $\begin{array}{l}\text { Critical illness poly- } \\
\text { neuropathy: RRR } 40 \\
(25-56), \text { ARR } 0.063 \\
(0.038-0.088), \text { NNT } 16 \\
(11-26)\end{array}$ & \\
\hline & & & & $\begin{array}{l}\text { Hypoglycemia: } \\
\text { RRR }-528 \% \\
(629 \text { to }-427 \%), \\
\text { ARR }-0.095 \\
(-0.013 \text { to }-0.077), \\
\text { NNH } 11(9-13)\end{array}$ & $\begin{array}{l}\text { Strict glucose control re- } \\
\text { duced in-hospital mortality } \\
\text { for patients with > } 3 \text { ICU } \\
\text { days but did not lead to } \\
\text { a difference in overall } \\
\text { in-hospital mortality }\end{array}$ \\
\hline & & & & $\begin{array}{l}\text { Mortality or neurological } \\
\text { sequelae in hypogly- } \\
\text { caemic patients: RRR } \\
50 \%(-237 \text { to } 100 \%) \text {, } \\
\text { ARR }-0.001(-0.005 \\
\text { to } 0.003), \mathrm{NNH} 1,000 \\
\text { (211 to infinite) }\end{array}$ & \\
\hline \multirow[t]{2}{*}{ [6] } & \multirow[t]{2}{*}{$\begin{array}{l}\text { Pediatric septic shock } \\
\text { patients }(n=57)\end{array}$} & \multirow[t]{2}{*}{$\begin{array}{l}\text { Single-center, } \\
\text { prospective observa- } \\
\text { tional cohort study } \\
(\text { level 2c) }\end{array}$} & \multirow[t]{2}{*}{ Mortality } & $\begin{array}{l}\text { Peak glucose level } \\
\text { in non-survivors } \\
262 \pm 110 \mathrm{mg} / \mathrm{dl} \\
(14.5 \pm 6 \mathrm{mmol} / \mathrm{l}) \text { was } \\
\text { higher than in survi- } \\
\text { vors: } 167.8 \pm 55 \mathrm{mg} / \mathrm{dl} \\
(9.5 \pm 3 \mathrm{mmol} / \mathrm{l} \text {; } \\
p<0.01)\end{array}$ & $\begin{array}{l}\text { Observational pediatric } \\
\text { study; univariate analysis } \\
\text { identified three possible } \\
\text { factors that could be as- } \\
\text { sociated with increased } \\
\text { mortality (higher glucose } \\
\text { level, male gender, pediatric } \\
\text { risk of mortality score II } \\
\text { above 10); multivariate } \\
\text { analysis demonstrated that } \\
\text { peak glucose level was the } \\
\text { only independent risk factor } \\
\text { associated with mortality }\end{array}$ \\
\hline & & & & $\begin{array}{l}\text { Best peak glucose level } \\
\text { predicting death was } \\
178 \mathrm{mg} / \mathrm{dl}(10 \mathrm{mmol} / \mathrm{l}) \\
\text { sensitivity } 0.71, \text { speci- } \\
\text { ficity } 0.72 \text {, relative risk } \\
\text { of death in hypergly- } \\
\text { caemic patients } 2.59 \\
(1.37-4.88)\end{array}$ & $\begin{array}{l}\text { Severity of illness was not } \\
\text { reported; } 941 \text { of } 1,927 \text { pati- } \\
\text { ents excluded because of } \\
\text { absence of glucose measure- } \\
\text { ment, leading to a possible } \\
\text { selection bias }\end{array}$ \\
\hline [5] & $\begin{array}{l}\text { Pediatric critically ill, } \\
\text { non-diabetic patients } \\
(n=942)\end{array}$ & $\begin{array}{l}\text { Single-center, retro- } \\
\text { spective observa- } \\
\text { tional cohort study } \\
(\text { level 2c) }\end{array}$ & $\begin{array}{l}\text { Mortality and length } \\
\text { of stay }\end{array}$ & \multicolumn{2}{|l|}{$\begin{array}{l}\text { Peak glucose level above } \\
150 \mathrm{mg} / \mathrm{dl}(8.3 \mathrm{mmol} / \mathrm{l}) \\
\text { within } 10 \text { days of initial } \\
\text { glucose measurement } \\
\text { predicted death with } \\
\text { a sensitivity of } 81 \% \\
(68-93 \%) \text {, specificity } \\
51 \%(48-54 \%) \text {, relative } \\
\text { risk of death } 4.13(1.83- \\
9.32) \text {; length of stay in } \\
\text { hyperglycaemic group } \\
\text { was higher } 6.1 \pm 9.6 \\
\text { vs. } 4.0 \pm 6.0 \text { days } \\
(p=0.001)\end{array}$} \\
\hline
\end{tabular}

Table 1 Continued 
in children may differ significantly from the hyperinsulinaemic hyperglycaemia associated with insulin resistance in adult sepsis. In a recent study it has been shown that children in shock due to meningococcal sepsis showed signs of insufficient insulin response to hyperglycaemia, whereas patients without signs of shock were insulin resistant [7]. In paediatric critically ill patients, hypoglycaemia is also prevalent and is related to increased mortality [8]. Hypoglycaemia was significantly more common in patients receiving intensive insulin therapy [4]. Insulin therapy in sick children with high blood glucose levels, exceeding $178 \mathrm{mg} / \mathrm{dl}$ (10 mmol/l), can be advocated, but based on current evidence, there is insufficient data to extrapolate to critically ill children that strict glucose control is beneficial. Currently, two large registered and ongoing European randomised controlled trials on the subject of tight glucose control in critically ill paediatric patients are being performed: Control of Hyperglycaemia in Paediatric Intensive Care (ISRCTN 61735247, London, http://www.chip-trial.org.uk) and Tight Glycemic Control With Intensive Insulin Treatment in PICU (NCT00214916, Leuven).

In conclusion, no randomised controlled studies focusing on strict glucose control in paediatric patients were found. In critically ill adults maintenance of strict normogly- caemia with intensive insulin therapy reduces morbidity and mortality (evidence grade A). In paediatric ill patients, hyperglycaemia is prevalent and levels above $178 \mathrm{mg} / \mathrm{dl}$ $(10 \mathrm{mmol} / \mathrm{l})$ are associated with increased mortality (grade B).Ill children, however, are also susceptible to hypoglycaemia. Based on current evidence, insulin therapy aimed at strict glucose control [blood glucose levels between 80 and $110 \mathrm{mg} / \mathrm{dl}$ (4.5-6 mmol/1)] cannot be recommended in paediatric critically ill patients. Any future change in practice should be based on evidence from current randomised clinical trials.

Open Access. This article is distributed under the terms of the Creative Commons Attribution Noncommercial License which permits any noncommercial use, distribution, and reproduction in any medium, provided the original author(s) and source are credited.

\section{References}

1. Muhlestein JB, Anderson JL, Horne BD, Lavasani F, Allen Maycock CA, Bair TL, Pearson RR, Carlquist JF (2003) Effect of fasting glucose levels on mortality rate in patients with and without diabetes mellitus and coronary artery disease undergoing percutaneous coronary intervention. Am Heart J 146:351-358

2. Suematsu Y, Sato H, Ohtsuka T, Kotsuka Y, Araki S, Takamoto S (2000) Predictive risk factors for delayed extubation in patients undergoing coronary artery bypass grafting. Heart Vessels 15:214-220
3. Van den Berghe G, Wouters P, Weekers F, Verwaest C, Bruyninckx F, Schetz M, Vlasselaers D, Ferdinande P, Lauwers P, Bouillon R (2001) Intensive insulin therapy in critically ill patients. N Engl J Med 345:1359-1367

4. Van den Berghe G, Wilmer A, Milants I, Wouters PJ, Bouckaert B, Bruyninckx F, Bouillon R, Schetz M (2006) Intensive insulin therapy in mixed medical/surgical intensive care units: benefit versus harm. Diabetes 55:3151-3159

5. Faustino EV, Apkon M (2005) Persistent hyperglycemia in critically ill children. J Pediatr 146:30-34

6. Branco RG, Garcia PC, Piva JP, Casartelli CH, Seibel V, Tasker RC (2005) Glucose level and risk of mortality in pediatric septic shock. Pediatr Crit Care Med 6:470-472

7. van Waardenburg DA, Jansen TC, Vos GD, Buurman WA (2006) Hyperglycemia in children with meningococcal sepsis and septic shock: the relation between plasma levels of insulin and inflammatory mediators. J Clin Endocrinol Metab 91:3916-3921

8. Wintergerst KA, Buckingham B, Gandrud L, Wong BJ, Kache S, Wilson DM (2006) Association of hypoglycemia, hyperglycemia, and glucose variability with morbidity and death in the pediatric intensive care unit. Pediatrics 118:173-179

D. G. Markhorst ( $)$ M. van Heerde •

F. B. Plötz - M. C. J. Kneyber

VU University Medical Center, Department of Paediatric Intensive Care, Office 8 D 12 , P.O. Box 7057, 1007 MB Amsterdam,

The Netherlands e-mail: dg.markhorst@vumc.nl

Tel.: +31-20-4442413

Fax: +31-20-4443045 